\title{
AVALIAÇÃO DA SUSTENTABILIDADE HÍDRICA DE JUIZ DE FORA/MG
}

\author{
Evaluation of the Water Sustainability at Juiz de Fora County/Minas Gerais \\ Christian Ricardo Ribeiro* \\ Henrique da Silva Pizzo**
}

\begin{abstract}
Resumo
Dada a necessidade de se garantir o abastecimento de água no século XXI, o trabalho teve como objetivo elaborar análises prospectivas sobre os recursos hídricos em âmbito municipal, sendo a pesquisa dividida em três etapas gerais: avaliação da quantidade hídrica disponível, avaliação da demanda hídrica e avaliação da capacidade hídrica de suporte. Os resultados obtidos mostram que o cenário atual aponta para a futura desativação de alguns mananciais e a conseqüente sobrecarga de outros. A avaliação da capacidade hídrica de suporte demonstrou que o Município de Juiz de Fora, de forma geral, ainda pode ser classificado como exportador hídrico. Porém, considerando-se a atual quantidade hídrica disponível, a população equivalente à qualidade hídrica já foi superada nos três cenários de crescimento demográfico considerados, sendo este o indicador mais restritivo entre aqueles analisados. Nessas mesmas condições, o indicador relativo à quantidade hídrica disponível seria superado, nos próximos 30 anos, apenas num cenário de crescimento demográfico máximo, revelando ser este o indicador menos restritivo entre aqueles analisados.
\end{abstract}

Palavras-chave: Abastecimento de água, demanda hídrica, disponibilidade hídrica, gestão de recursos hídricos, sustentabilidade hídrica.

\begin{abstract}
In the Triângulo Mineiro area are rare and beautiful examples of abiotic natural heritage, such as waterfalls in Given the need to guarantee the water supply at the XXI century, the search had as its objective prepare prospective analysis on the water resources at the municipal scope, been the work divided into three general steps: evaluation of the quantity of available water, evaluation of the water demand and evaluation of the water capacity to support. The obtained results show that the current scene points to the future deactivation of some sources and the consequent overload of others. The evaluation of the water capacity to support showed that the Juiz de Fora County, generally, still can be classified as exporting water. Therefore, if we take into consideration the current quantity of available water, the equivalent population of the water quality was overcome at the three scenes of demographic growth considered, been this the more restrictive indicator among those that were analysed. By the same conditions, the relative indicator of the quantity of available water would be overcome, by the next 30 years, just a scene of maximum demographic growth, revealing to be this indicator the less restrictive among those that were analysed.
\end{abstract}

Key words: Water supply,, water demand, water availability, management of the water resources, water sustainability

\begin{abstract}
Resumen
La preocupación por garantizar el abastecimiento de agua en el siglo XXI es la justificación para analizar prospectivamente las condiciones de los recursos hídricos en el ámbito municipal. La investigación se dividió en tres etapas: evaluación de la cantidad de agua disponible, evaluación de la demanda hídrica y evaluación de la capacidad hídrica de soporte. Los resultados obtenidos muestran que el escenario actual registra una futura desactivación de algunos de las fuentes hídricas y la consecuente sobrecarga de otros. La evaluación de la capacidad hídrica de soporte demostró que el municipio de Juiz de Fora, de forma general, aun puede ser clasificado como exportador hídrico; sin embargo, al considerar la actual cantidad hídrica disponible, la población equivalente a la calidad hídrica ya fue superada en los tres escenarios de crecimiento demográfico evaluados, siendo este el indicador más restrictivo entre los analizados. En esas condiciones, el indicador relativo a la cantidad hídrica disponible será superado en los próximos 30 años, apenas en un escenario de crecimiento demográfico máximo, relevando ser éste el indicador menos restrictivo entre los considerados.
\end{abstract}

Palabras clave: Abastecimiento de agua, demanda hídrica, disponibilidad hídrica, gestión de recursos hídricos, sustentabilidad hídrica.

(*) Mestrando na Pós-Graduação em Geografia da Universidade Estadual Paulista/Presidente Prudente - Rua Roberto Simonsen, 305 - Caixa Postal: 266 - CEP: 19060-900 - Presidente Prudente/(SP) - Brasil, Tel. (+55 18) 39022790 - christianric@hotmail.com

(**) Dr. em Engenharia Civil pela Universidade Estadual de Campinas, Técnico da Companhia de Saneamento Municipal - Av. Barão do Rio Branco, 1843 - 10ªndar, CEP: 36.013-020 - Juiz de Fora (MG) - Brasil, Tel: (+55 32) 32391236 - hpizzo@gmail.com 


\section{INTRODUÇÃO}

É consenso que os recursos hídricos constituem um dos elementos mais relevantes na discussão da crise ambiental que se coloca como um dos principais desafios a serem enfrentados pela humanidade no século XXI. Entre todos os recursos naturais de que o homem dispõe, a água aparece como um dos mais importantes, sendo indispensável à sua própria sobrevivência no planeta Terra. Desse fato decorre a vital importância de sua conservação, ou seja, sua utilização racional pela espécie humana.

A crise da água está inserida em um contexto maior que é a crise ambiental mundial e pode ser melhor compreendida a partir de quatro realidades: a distribuição desigual dos recursos hídricos na superfície terrestre; todos os fatores relacionados ao desperdício e ao mau gerenciamento dos recursos hídricos disponíveis; o contexto cada vez mais alarmante de poluição e contaminação dos recursos hídricos; e o crescimento populacional, especialmente nos países subdesenvolvidos.

Esse quadro de crise reforça a necessidade do manejo adequado dos recursos hídricos, compatibilizando-se os seus diversos usos, de forma a garantir a água na quantidade e na qualidade desejáveis aos seus diversos fins. Disso decorre também a necessidade premente de se rediscutir o modelo de desenvolvimento, o padrão de consumo, a desigual distribuição de riqueza e o padrão tecnológico existentes no mundo atual. Para isso, é fundamental compreender o sistema produtivo e os processos que causam tantos desequilíbrios na natureza.

Localizado na Mesorregião Geográfica Zona da Mata Mineira, o Município de Juiz de Fora é um dos principais centros urbanos do Estado de Minas Gerais. Contando com uma população de 526.706 habitantes (IBGE, 2009) e sofrendo um intenso processo de urbanização nas últimas décadas, o município convive com os benefícios e com os problemas decorrentes desse processo, nem sempre precedido por um planejamento eficiente.

Nas últimas décadas novos vetores de expansão urbana se delinearam, principalmente nos setores noroeste e oeste do município, justamente nas áreas onde se localizam os seus mananciais de abastecimento público de água. A intensa urbanização das bacias hidrográficas desses mananciais, somada à falta de planejamento do uso e ocupação do solo, tem ocasionado uma sensível degradação da qualidade de suas águas. Além disso, alguns mananciais do município estão se tornando inoperantes, como a Represa do Poço D'Antas, cujo sistema de produção de água foi desativado em 2006, e a Represa de São Pedro, que nos próximos anos pode deixar de compor o sistema municipal de abastecimento caso não sejam tomadas as medidas necessárias à recuperação ambiental de sua bacia hidrográfica. $\mathrm{O}$ crescimento urbano desordenado e o aumento de demandas públicas motivado pela concentração demográfica podem trazer impactos negativos sobre a água utilizada para o abastecimento público nas cidades.

A sustentabilidade hídrica implica justamente em se manter um equilíbrio dinâmico entre a oferta e a demanda por água, de modo que os mananciais - superficiais e/ou subterrâneos - sejam utilizados a taxas iguais ou inferiores à sua capacidade de regeneração. Logo, a sustentabilidade hídrica em áreas urbanas perpassa pela tentativa de uma conjugação harmônica de vários fatores, entre os quais quatro se destacam: a quantidade hídrica disponível, a qualidade hídrica, a demanda hídrica e a capacidade de urbanização. Esses fatores devem ser relacionados às tendências de crescimento demográfico municipais, já que as mesmas têm um papel fundamental no comportamento da demanda e no processo de expansão urbana que, por sua vez, podem exercer uma pressão sobre o sistema de abastecimento púbico de água, requerendo uma maior disponibilidade hídrica.

Assim, justifica-se a necessidade de estudos que avaliem a disponibilidade e a demanda hídricas dentro de uma perspectiva de sustentabilidade na utilização do recurso natural água, valendo-se do estímulo decorrente da criação de um novo arcabouço legal que dá suporte à gestão dos recursos hídricos no país - sobretudo a Lei Federal n. ${ }^{\circ}$ 9.433/1997 -, em especial em municípios de médio porte, que vêm apresentando um expressivo crescimento demográfico nos últimos anos. Dentro desse contexto, objetiva-se elaborar análises prospectivas sobre os recursos hídricos 
em âmbito municipal, baseadas na capacidade de suporte dos recursos hídricos, analisada a partir do cotejo entre três vertentes principais - o balanço entre a disponibilidade e a demanda hídricas, a dinâmica demográfica e o arcabouço legal pertinente.

\section{METODOLOGIA}

O trabalho foi desenvolvido em três etapas principais, conforme metodologia proposta por Francisco (2004, p. 43), incluindo: a avaliação da quantidade hídrica disponível, a avaliação da demanda hídrica e a análise da capacidade hídrica de suporte do Município de Juiz de Fora. Em todas as etapas do trabalho foram utilizados os dados sócio-ambientais provenientes de extensa pesquisa bibliográfica realizada nos trabalhos já produzidos sobre o Município de Juiz de Fora. Os dados sócio-ambientais levantados abasteceram o sistema, que foi sendo realimentado e realimentou todas as etapas do trabalho. Os dados sócio-ambientais foram devidamente organizados e tratados, permitindo a geração de produtos intermediários como tabelas, gráficos e mapas temáticos.

A estimativa da quantidade hídrica disponível foi realizada através da análise de dados hidrológicos dos mananciais destinados ao abastecimento público de água do Município de Juiz de Fora, fornecidos pela Companhia de Saneamento Municipal (CESAMA). Assim, a quantidade hídrica disponível do Município de Juiz de Fora resultou do somatório da disponibilidade hídrica das bacias hidrográficas dos mananciais atualmente destinados ao abastecimento público de água. Foi também avaliada a quantidade hídrica disponível do município caso sejam incorporados ao sistema de abastecimento a Represa de Chapéu D'Uvas e o Ribeirão da Estiva, tal como foi previsto pelo Plano Diretor de Abastecimento de Água da Área Urbana de Juiz de Fora (PDAA-AUJF), elaborado em 1985. O plano previu também a otimização da vazão de regularização dos sistemas Norte e Dr. João Penido, o que poderia ser alcançado com a construção de novos barramentos e reservatórios. Essa última possibilidade também foi analisada neste trabalho.

Já a demanda hídrica foi estimada com base em dados de hidrometração fornecidos pela CESAMA e em dados demográficos e sócio-econômicos fornecidos pelo IBGE. A demanda hídrica total do Município de Juiz de Fora resultou do somatório das demandas hídricas residencial, industrial, comercial e pública referentes ao ano de 2008.

A partir do cruzamento das informações obtidas nas duas etapas anteriores, foi realizado o balanço entre a quantidade hídrica disponível e a demanda hídrica, o que permitiu a avaliação da disponibilidade hídrica do município. Dessa forma, tal avaliação baseou-se no cotejo entre a produção atual de água do município e o grau de utilização dos recursos hídricos.

A estimativa da capacidade hídrica de suporte do Município de Juiz de Fora foi realizada a partir do balanço entre a quantidade hídrica disponível, a demanda hídrica, a qualidade hídrica e a disponibilidade de áreas à ocupação urbana. Isso permitiu a classificação do município quanto à capacidade hídrica de suporte.

Todas as quatro variáveis foram expressas em uma unidade comum, denominada população equivalente, que representa o número hipotético de habitantes equivalente ao resultado da adoção de determinadas condições de uso de cada parâmetro, representando uma situação limite. Os resultados de população equivalente foram cruzados com as tendências demográficas do município. Desta forma foi possível identificar quando a situação limite do uso dos recursos hídricos e do solo urbano pode ser atingida em função da dinâmica demográfica.

\section{RESULTADOS E DISCUSSÃO}

\section{Quantidade hídrica disponível}

A disponibilidade hídrica para a outorga é a parcela da disponibilidade no sistema que ficará disponibilizada para uso, sendo esta "dependente da legislação, do sistema jurídico, da escolha 
entre diferentes critérios possíveis de definição de reservas ambientais, de prioridades de uso atuais e de gerações futuras, os quais podem advir de negociações entre usuários e sociedade" (CRUZ, 2001, p. 61). A vazão de um rio varia muito ao longo do ano, sendo necessário conhecer essa variabilidade para melhor definir a disponibilidade natural do rio no atendimento da demanda. É uma prática usual a definição de indicadores de vazão que subsidiem o processo de concessão de outorga de direito de uso de recursos hídricos. Adota-se uma vazão de referência, que corresponde a "um valor de vazão que passa a representar o limite superior de utilização da água em um curso d'água" (CRUZ, 2001, p.147).

A quantidade hídrica disponível do Município de Juiz de Fora foi estimada através de dados hidrológicos fornecidos por uma fonte básica de pesquisa: o Plano Diretor de Abastecimento de Água da Área Urbana de Juiz de Fora (PDAA-AUJF), sobretudo o Volume IV - Recursos Hídricos (LEME, 1985), que apresentou estudos de avaliação da disponibilidade hídrica em Juiz de Fora, buscando subsidiar a pré-seleção dos mananciais que poderiam servir como fonte de abastecimento de água para o município.

É importante ressaltar que a Portaria IGAM n. ${ }^{\circ}$ 10/1998 adota a Q7,10 como a vazão de referência para a concessão de outorga de direito de uso de recursos hídricos no Estado de Minas Gerais e estabeleceu que a vazão máxima outorgável para a captação direta nos cursos d'água é igual a $30 \%$ da Q7,10. Logo, a manutenção de vazão residual mínima deve ser igual a 70\% da Q7,10. Porém, a portaria define também que, nos casos em que houver regularização, vazão maior pode ser retirada desde que garantido o fluxo residual mínimo de 70\% da Q7,10. A questão da manutenção dos fluxos residuais de jusante foi também objeto da atenção do PDAA-AUJF e merece destaque por se tratar de uma condição fundamental a ser cumprida para o aproveitamento sustentável dos mananciais destinados ao abastecimento de água. Assim, a vazão a ser explorada em cada um dos mananciais selecionados pelo plano leva em conta a necessidade de manutenção da vazão de jusante e, conseqüentemente, atende aos requisitos elencados pela referida portaria.

Em função disso, adotou-se como quantidade hídrica disponível os valores apresentados pelo PDAA-AUJF. No caso de São Pedro e Poço D'Antas foram adotados, respectivamente, os valores de $0,08 \mathrm{~m} 3 / \mathrm{s}$ e $0,025 \mathrm{~m} 3 / \mathrm{s}$ como quantidade hídrica disponível desses mananciais, que correspondem à captação normal dos mesmos. No caso dos sistemas Norte e Dr. João Penido pode-se considerar duas situações distintas. A primeira, mais restritiva e que corresponde à realidade atual, adota como quantidade hídrica disponível a atual capacidade de produção de água desses dois sistemas, que é de, respectivamente, $505 \mathrm{~L} / \mathrm{s}$ e $800 \mathrm{~L} / \mathrm{s}$. Uma outra situação, um pouco mais confortável, considera a otimização da vazão de regularização dos dois sistemas, o que seria possível através da construção dos barramentos previstos pelo PDAA-AUJF em 1985. Assim, a quantidade hídrica disponível do Sistema Norte subiria para $2,056 \mathrm{~m} 3 / \mathrm{s}$ e a do Sistema Dr. João Penido para $0,940 \mathrm{~m} 3 / \mathrm{s}$. No caso da Represa de Chapéu D'Uvas foi adotado o valor de 4,0 m3/s, tal como definido pelo PDAA-AUJF e que corresponde à captação máxima do mesmo. No caso do Ribeirão da Estiva foi adotado o valor de $0,71 \mathrm{~m} 3 / \mathrm{s}$, valor que poderia ser alcançado com a construção dos barramentos previstos pelo PDAA-AUJF no Córrego Serafim e no Córrego Varginha.

Os valores de quantidade hídrica disponível podem variar significativamente. $\mathrm{O}$ cenário mais confortável (bastante diferente da realidade atual) adota o valor de 7,81 m3/s como quantidade hídrica disponível, incluindo a utilização de todos os mananciais previstos pelo PDAA-AUJF e a otimização da vazão de regularização dos sistemas Norte e Dr. João Penido. Já o cenário mais restritivo adota o valor de $1,305 \mathrm{~m} 3 / \mathrm{s}$ como quantidade hídrica disponível, prevendo a desativação do Sistema São Pedro antes da incorporação da Represa de Chapéu D'Uvas e do Ribeirão da Estiva ao sistema de abastecimento de água do município e a manutenção da atual capacidade de produção de água dos Sistemas Norte Dr. João Penido. 


\section{Demanda hídrica}

A demanda hídrica pode ser definida como "a quantidade necessária de água para suprir as necessidades dos usuários" (CRUZ, 2001, p. 61). Na literatura relativa à gestão de recursos hídricos considera-se a divisão entre usos consuntivos e usos não-consuntivos.

Os usos consuntivos da água "são aqueles que retiram a água de seus mananciais, através de captações ou derivações, e apenas parte dessa água retorna às suas fontes de origem" (CARRERA-FERNANDEZ e GARRIDO, 2003, p. 22). Exemplos de usos consuntivos são a agricultura irrigada, o abastecimento humano rural e urbano, a dessedentação de animais e o abastecimento industrial. Nesse tipo de uso a água efetivamente retirada torna-se indisponível no manancial.

Já os usos não-consuntivos da água "são aqueles que utilizam a água em seus próprios mananciais sem haver necessidade de retirá-la ou, após captada, retorna integralmente a seus mananciais" (CARRERA-FERNANDEZ e GARRIDO, 2003, p. 23). Exemplos de usos desse tipo são a pesca, o lazer e a recreação, a navegação fluvial e a preservação ambiental, que aproveitam a disponibilidade da água em sua própria fonte, sem qualquer modificação quantitativa significativa, além da diluição de efluentes e da geração de energia elétrica. Uma das vantagens dos usos não-consuntivos dos recursos hídricos é que esses podem, em geral, ser combinados com outros usos, extraindo-se de seus mananciais benefícios múltiplos.

A estimativa da demanda hídrica total do Município de Juiz de Fora foi realizada com base no somatório das demandas hídricas residencial (população residente), comercial, industrial e pública. Para tal, foram utilizados os dados fornecidos pela CESAMA, constantes dos Relatórios de dados financeiros: faturamento e arrecadação - água e esgoto - referentes a 2008, que registram os volumes mensais micromedidos de consumo de água em Juiz de Fora por setor usuário (residencial, comercial, industrial e público). Considerou-se que o consumo hídrico e a demanda hídrica são equivalentes, tendo-se em vista que a quantidade de água requerida para o desenvolvimento das atividades humanas no Município de Juiz de Fora corresponde à quantidade de água que foi efetivamente utilizada para tais fins. A Tabela 1 apresenta esses dados.

Tabela 1 - Volumes mensais micromedidos (m3) de consumo de água por setor usuário em Juiz de Fora em 2008

\begin{tabular}{l|r|r|r|r}
\hline \multicolumn{1}{r|}{ METORES } & \multicolumn{1}{c|}{ Residencial } & \multicolumn{1}{c}{ Comercial } & Industrial & \multicolumn{1}{c}{ Público } \\
\hline Janeiro & 1.817 .818 & 232.254 & 60.023 & 92.213 \\
\hline Fevereiro & 2.002 .436 & 245.815 & 69.900 & 104.470 \\
\hline Março & 1.854 .360 & 238.035 & 61.111 & 100.333 \\
\hline Abril & 1.900 .006 & 249.957 & 69.256 & 105.522 \\
\hline Maio & 1.758 .529 & 235.076 & 64.788 & 102.251 \\
\hline Junho & 1.761 .987 & 238.145 & 69.669 & 103.143 \\
\hline Julho & 1.920 .010 & 251.220 & 76.810 & 96.164 \\
\hline Agosto & 1.942 .594 & 256.053 & 67.625 & 140.623 \\
\hline Setembro & 1.918 .422 & 260.737 & 77.069 & 108.150 \\
\hline Outubro & 1.863 .365 & 250.521 & 64.255 & 103.185 \\
\hline Novembro & 1.759 .537 & 247.403 & 61.200 & 105.735 \\
\hline Dezembro & 2.086 .542 & 259.059 & 57.398 & 101.127 \\
\hline Total & 22.585 .606 & 2.964 .275 & 799.104 & 1.262 .916 \\
\hline
\end{tabular}

Fonte: Assessoria de Planejamento e Controladoria da CESAMA.

Os dados de demanda hídrica residencial apresentados na Tabela 1 correspondem praticamente à demanda hídrica residencial total de Juiz de Fora, já que, atualmente, o sistema de abastecimento de água operado pela CESAMA atende a cerca de $99,8 \%$ da população urbana de Juiz de Fora (MKM, 2002, p. 06 - Vol. I) e esta, por sua vez, representa 99,17\% da população total do município (MKM, 
2002, p. 04 - Vol. I). Além disso, o índice de hidrometração no município chega a 99,9\% (MKM, 2002, p. 08 - Vol. I), o que garante a confiabilidade dos dados e torna-os perfeitamente representativos da demanda hídrica total do município. Como se percebe, a demanda hídrica residencial de Juiz de Fora é responsável por mais de $80 \%$ da demanda hídrica total do município.

Para efeito de cálculo da demanda hídrica total de Juiz de Fora levou-se em consideração o somatório do consumo de água dos quatro setores usuários (residencial, comercial, industrial e público) em 2008. Assim, chega-se a uma demanda hídrica total para o Município de Juiz de Fora igual a $27.611 .901 \mathrm{~m} 3 /$ ano $(75.650,0 \mathrm{~m} 3 /$ dia ou $0,88 \mathrm{~m} 3 / \mathrm{s})$.

Adotando-se como quantidade hídrica disponível o valor de $7,81 \mathrm{~m} 3 / \mathrm{s}$, referente ao somatório da vazão aproveitável das bacias hidrográficas dos mananciais atualmente destinados ao abastecimento público de água do município e daqueles que apresentam potencial efetivo de utilização, atendidos os requisitos legais previstos pela Portaria IGAM n. ${ }^{\circ}$ 10/1998, a relação entre a demanda hídrica e a quantidade hídrica disponível é de aproximadamente 11,3\%. Ainda que se dobrasse a demanda hídrica residencial, elevando-a a um patamar de $1,44 \mathrm{~m} 3 / \mathrm{s}$, essa relação seria de aproximadamente $18,4 \%$.

\section{Balanço entre a quantidade hídrica disponível e a demanda hídrica}

Os resultados da avaliação da quantidade hídrica disponível e da demanda hídrica foram cruzados, dando origem a indicadores que expressam o balanço hídrico atual do Município de Juiz de Fora: (a) a quantidade hídrica per capita disponível e (b) a relação entre a demanda hídrica e a quantidade hídrica disponível.

Deve-se ressaltar aqui a desigual distribuição espacial da população e das águas superficiais em Juiz de Fora: a área urbana, que ocupa 32\% da superfície do município, concentra 99,17\% de sua população total. Essa população é responsável pela quase totalidade da demanda hídrica residencial do município e por pouco mais de $80 \%$ da demanda hídrica total. Enquanto isso, a Bacia Hidrográfica da Represa de Chapéu D’Uvas, localizada em território dos municípios de Ewbanck da Câmara e Santos Dumont, distante aproximadamente $38 \mathrm{~km}$ do centro de Juiz de Fora, concentra pouco mais de $50 \%$ da quantidade hídrica disponível.

Considerando a utilização de todos os mananciais previstos pelo PDAA-AUJF com a vazão de regularização otimizada $(7,81 \mathrm{~m} 3 / \mathrm{s})$ e a demanda hídrica atual $(0,88 \mathrm{~m} 3 / \mathrm{s})$, conclui-se que apenas aproximadamente $11,3 \%$ da quantidade hídrica disponível estão sendo consumidos. Tem-se ainda uma quantidade hídrica per capita disponível igual a aproximadamente 473,1 m3/hab.ano (considerando uma população de 520.612 habitantes, segundo estimativa populacional do IBGE para $1 .^{\circ}$ de julho de 2008). De acordo com os parâmetros propostos por Francisco (2004, p. 132), poder-se-ia classificar o Município de Juiz de Fora com uma região hidrográfica de média a alta disponibilidade hídrica. Em relação à quantidade hídrica disponível per capita, o município poderia ser classificado como uma região hidrográfica com disponibilidade hídrica média. Porém, considerando a relação entre a quantidade hídrica disponível e a demanda hídrica atual, o município poderia ser classificado como uma região hidrográfica de disponibilidade hídrica alta, caracterizando o cenário mais confortável.

Se no cálculo da quantidade hídrica disponível do município levar-se em consideração a utilização somente dos mananciais atualmente destinados ao abastecimento público de água (sistemas Norte, Dr. João Penido e São Pedro) e adotar-se a atual capacidade de produção de água dos sistemas Norte e Dr. João Penido como quantidade hídrica disponível dos mesmos, já que a otimização da vazão de regularização proposta pelo PDAA-AUJF ainda não foi concretizada pela CESAMA, a quantidade hídrica total é igual a 1,305 m3/s. Somada a quantidade hídrica disponível do Sistema São Pedro, tem-se uma quantidade hídrica disponível de 1,385 m3/s. Levando-se em consideração a demanda hídrica atual $(0,88 \mathrm{~m} 3 / \mathrm{s})$, pode-se concluir que $63,5 \%$ da quantidade hídrica disponível já estão sendo consumidos. A quantidade hídrica per capita disponível seria de aproximadamente 83,9 
m3/hab.ano. Dessa forma, o município poderia ser classificado como uma região hidrográfica com disponibilidade hídrica variando entre insuficiente e baixa, caracterizando o cenário mais restritivo.

Avaliação da capacidade hídrica de suporte

a) População equivalente à quantidade hídrica disponível

A população equivalente à quantidade hídrica disponível corresponde à razão entre a quantidade hídrica disponível futura e a demanda hídrica per capita atual.

Para o cálculo da quantidade hídrica disponível foram analisados vários cenários de utilização dos recursos hídricos do município. Considerou-se desde a possibilidade de utilização de todos os mananciais previstos pelo PDAA-AUJF em 1985 (Represa Dr. João Penido, Represa de São Pedro, Represa do Poço D’Antas, Ribeirão do Espírito Santo, Represa de Chapéu D’Uvas e Ribeirão da Estiva) até a utilização de apenas dois mananciais, que estão entre aqueles atualmente explorados (Represa Dr. João Penido e Ribeirão do Espírito Santo). Levou-se em consideração ainda a possibilidade de otimização da vazão de regularização dos sistemas Norte e Dr. João Penido, o que pode ser alcançado com a construção dos reservatórios previstos pelo PDDA-AUJF em 1985. Considerou-se também a possibilidade de se adotar a atual capacidade de produção de água dos mananciais atualmente destinados ao abastecimento público de água como quantidade hídrica disponível.

Como consumo per capita médio de água foi adotado o valor atual (2008) de aproximadamente 145 l/hab.dia, que corresponde à relação entre a demanda hídrica total (incluídas aí as demandas hídricas residencial, comercial, industrial e pública) e o atual número de habitantes do município (2008). Optou-se pela manutenção da taxa de consumo atual em função dos seguintes fatores: a tendência de queda do consumo per capita médio de água em Juiz de Fora através da análise dos dados dos últimos dez anos disponibilizados pelo Sistema Nacional de Informações sobre Saneamento; o alto índice de hidrometração registrado pela CESAMA, que já em 1999 era de 100\%, pois a universalização dos serviços de cadastramento das economias e de instalação de medidores certamente pode contribuir para a redução do desperdício de água nos domicílios; a queda contínua das perdas na distribuição de água, que passaram de 40,71\% em 1999 para 28,49\% em 2006; e a tendência de queda do consumo urbano per capita médio de água (queda de 164,63 1/hab.dia para 154,69 1/hab.dia no período 2002-2005) mesmo diante da tendência de elevação da renda per capita (elevação de R \$ 8.126,00 para R\$10.489,00 no período 2002-2005) (IBGE, 2005).

Serão analisados apenas os dois cenários extremos. Levando-se em consideração todos os mananciais previstos pelo PDAA-AUJF para compor o futuro sistema de abastecimento de água de Juiz de Fora e ainda a otimização da vazão de regularização dos sistemas Norte e Dr. João Penido, com a construção dos barramentos previstos no plano, tem-se uma quantidade hídrica disponível da ordem de 7,81 m3/s. Adotando-se este valor como quantidade hídrica disponível e um consumo per capita médio de água igual a aproximadamente 145 1/hab.dia, tem-se uma população equivalente igual a aproximadamente 4.653.682 habitantes. Esse valor resulta da adoção de um valor máximo de quantidade hídrica disponível, sendo nove vezes superior à atual população do município, o que demonstra a sua relativa abundância de recursos hídricos.

No cenário em que considera-se a desativação da Represa de São Pedro antes da incorporação da Represa de Chapéu D'Uvas e do Ribeirão da Estiva ao sistema de abastecimento de água municipal e a adoção da atual capacidade de produção de água dos sistemas Norte e Dr. João Penido como a sua quantidade hídrica disponível, tem-se uma quantidade hídrica disponível total de 1,305 $\mathrm{m} 3 / \mathrm{s}$ e uma população equivalente igual a 777.600 habitantes. Esse seria o cenário mais restritivo, resultante da adoção de um valor mínimo de quantidade hídrica disponível. Porém, verifica-se que tal quantidade hídrica disponível ainda permite abastecer uma população superior em uma vez e meia à população atual do município. 
b) População equivalente à qualidade hídrica

Os novos paradigmas que norteiam a gestão dos recursos hídricos enfatizam, como condição de disponibilidade hídrica, a ligação indissociável entre quantidade e qualidade. A influência da qualidade da água na disponibilidade hídrica se dá tanto pela impossibilidade de sua captação para determinados fins, devido ao seu elevado grau de contaminação, quanto pela necessidade de manutenção de um certo volume de água no corpo d'água para a diluição de poluentes. A esse respeito, Mota (1995, p. 03) afirma que "a qualidade desejada para determinado recurso hídrico vai depender dos usos para os quais o mesmo se destina". Branco e Rocha (1977, p. 93) elencaram vários parâmetros a serem considerados na definição do padrão de qualidade a ser adotado para as águas utilizadas para consumo público, mediante tratamento convencional. São eles: DBO (Demanda Bioquímica de Oxigênio), OD (Oxigênio Dissolvido), concentração de bactérias coliformes, substâncias tóxicas, material sobrenadante e fenóis.

A população equivalente à qualidade hídrica de Juiz de Fora foi estimada com base no limite da DBO, utilizado como critério de enquadramento dos corpos d'água de acordo com a classificação das águas adotada pelo Conselho Nacional do Meio Ambiente (CONAMA), e no nível de eficiência do tratamento do esgoto na eliminação da DBO. A Resolução CONAMA n. ${ }^{\circ}$ 357, de 17 de março de 2005, estabeleceu 13 classes de qualidade das águas doces, salinas e salobras do Território Nacional, segundo a qualidade requerida para os seus usos preponderantes, indicando também os limites e as condições mínimas de qualidade da água para cada classe.

A concentração da DBO no corpo d'água receptor (DBOreceptor), após o lançamento do esgoto, deve ser igual ou inferior ao valor permitido para uma determinada classe de uso do CONAMA. Logo, ela é função da concentração da DBO no esgoto (DBOefluente) e do nível de eficiência do tratamento na eliminação da DBO do efluente $(\mathrm{K})$. Logo pode-se concluir que a razão entre a vazão do corpo d'água receptor (Qreceptor) e a vazão do efluente (Qefluente) é inversamente proporcional à razão entre a DBOreceptor e a DBOefluente.

Quanto menos restritiva a classe de uso do CONAMA e quanto maior for o nível de eficiência do tratamento do efluente, menor é a vazão necessária para a diluição da DBOefluente. A Tabela 2 apresenta a relação entre a vazão do corpo d'água receptor e a vazão do efluente segundo o enquadramento nas classes de uso do CONAMA (Resolução n. ${ }^{\circ}$ 357/2005) e o nível de eficiência do tratamento na eliminação da DBO do esgoto in natura.

Tabela 2 - Relação entre a vazão do corpo d'água receptor e a vazão do efluente segundo o enquadramento nas classes de uso definidas pela Resolução CONAMA n. ${ }^{\circ}$ 357/2005 e o nível de eficiência do tratamento na eliminação da DBO do esgoto in natura

\begin{tabular}{|c|c|c|c|}
\hline DBO permitida $(\mathrm{mg} / \mathrm{L})^{(\mathbf{1})}$ & Classe 1 & Classe 2 & Classe 3 \\
\hline Nível de eficiência do tratamento ${ }^{(2)}$ & 3 & 5 & 10 \\
\hline $0 \%$ & 83 & 50 & 25 \\
\hline $65 \%$ & 29 & 18 & 9 \\
\hline $75 \%$ & 21 & 13 & 6 \\
\hline $85 \%$ & 13 & 8 & 4 \\
\hline $95 \%$ & 4 & 3 & 1 \\
\hline
\end{tabular}

Fontes: (1) Resolução CONAMA n. ${ }^{\circ}$ 357/2005 e (2) EDDY e METCALF (1981) apud FRANCISCO (2004, p. 140).

Para expressar a capacidade hídrica de suporte do corpo receptor em termos de Popqualidade hídrica, considerou-se que:

- A vazão máxima de efluente a ser lançado no corpo d'água receptor não deve exceder a vazão crítica que pode ser captada para consumo (Qquantidade hídrica disponível), tal como 
estabelecido pela Portaria IGAM n. ${ }^{\circ}$ 10/1998, que trata da outorga de direito de uso de recursos hídricos no Estado de Minas Gerais. Dessa forma, numa situação crítica de escassez hídrica, deve restar no corpo d'água receptor uma vazão equivalente à vazão mínima definida pela legislação atualmente em vigor;

- O consumo per capita médio de água adotado (145 1/hab.dia) expressa o consumo conjunto de água dos setores residencial, comercial, industrial e público.

Para se enquadrar em determinada classe de uso do CONAMA, é necessário que a Qefluente seja menor do que a Qreceptor. Dessa forma, a Pop.qualidade hídrica corresponde, segundo Francisco (2004, p. 140), a:

Popqualidade hídrica $=$ Popquantidade hídrica disponível * (Qefluente/Qreceptor) $(1)$, onde:

Popquantidade hídrica disponível = Qquantidade hídrica disponível/Consumo per capita médio de água (2)

É importante ressaltar que estes valores não consideram a capacidade de autodepuração dos corpos d'água, o que resultaria em valores maiores de população equivalente à qualidade hídrica.

A proposta elaborada pela empresa MKM Engenharia Ambiental para o tratamento dos esgotos domésticos do Município de Juiz de Fora, a ser implementada até o ano 2023, caso seja de fato efetivada, permitirá o tratamento de $90 \%$ dos esgotos domésticos do município, com altíssimos índices de remoção da DBO e subsidiando a manutenção do enquadramento do Rio Paraibuna na Classe 2 do CONAMA.

Neste trabalho considerou-se a relação Qreceptor $\geq 3$ Qefluente, ou seja, que a vazão do corpo receptor deve ser maior ou igual a 3 vezes a vazão do efluente. Dessa forma, serão considerados o enquadramento das águas do Rio Paraibuna na Classe 2 e um nível de eficiência do tratamento de esgotos da ordem de $95 \%$. Considerou-se também o tratamento dos esgotos domésticos de $100 \%$ dos domicílios do município.

Dentro das condições apresentadas acima e levando-se em consideração todos os mananciais previstos pelo PDAA-AUJF para compor o futuro sistema de abastecimento de água de Juiz de Fora e ainda a otimização da vazão de regularização dos sistemas Norte e Dr. João Penido, com a construção dos barramentos previstos no plano, temos uma população equivalente à quantidade hídrica disponível igual a aproximadamente 4.653 .682 habitantes e, conseqüentemente, uma população equivalente à qualidade hídrica igual a aproximadamente 1.551.227 habitantes.

Outro cenário possível é aquele que prevê a desativação da Represa de São Pedro antes da incorporação da Represa de Chapéu D’Uvas ao sistema de abastecimento de água municipal e a adoção da atual capacidade de produção de água dos sistemas Norte e Dr. João Penido como a sua quantidade hídrica disponível. Nesse caso teremos uma população equivalente à quantidade hídrica disponível igual a 777.600 habitantes e uma população equivalente à qualidade hídrica igual a 259.200 habitantes. Esse seria o cenário mais restritivo, resultante da adoção de um valor mínimo de quantidade hídrica disponível. Neste cenário, verifica-se que a população atual do município, que continua a crescer, já representa pouco mais de duas vezes a população equivalente à qualidade hídrica.

c) População equivalente à disponibilidade de áreas à ocupação urbana

A população equivalente à disponibilidade de áreas à ocupação urbana foi estimada em função da extensão das áreas sem restrições legais à ocupação urbana e da aplicação das taxas de densidade demográfica. Para tal, foram utilizados os estudos realizados pelo Plano Diretor de Desenvolvimento Urbano (PJF, 2004) relativos ao macrozoneamento da cidade e os estudos da MKM Engenharia 
Ambiental (MKM, 2002 - Vol. I) para a concepção do sistema de esgotamento sanitário de Juiz de Fora. Inicialmente, é importante destacar que as áreas atualmente adensadas, como é o caso da área central de Juiz de Fora, dificilmente apresentarão padrão de crescimento semelhante ao de áreas periféricas, seja pela verticalização das construções, seja pela ampliação da mancha urbana.

A divisão das áreas da macha urbana foi realizada em função das Regiões Urbanas (RUs) adotadas pela administração municipal. A análise do crescimento populacional de cada RU somente tornou-se possível graças à existência de dados censitários dos anos de 1991, 1996 e 2000 por RU.

Além da análise do crescimento populacional foi necessário estabelecer a área máxima urbanizável para cada RU e fixar um limite de adensamento demográfico que representasse a saturação da área urbanizada. Para determinação do espaço urbanizável em cada RU foi utilizado o estudo de macrozoneamento da cidade, sugerido nas proposições do Plano Diretor de Desenvolvimento Urbano (PJF, 2004).

As Macroáreas definidas como áreas urbanizáveis de adensamento restrito e áreas de ocupação restrita foram consideradas áreas não urbanizáveis para efeito de concepção do projeto do esgotamento sanitário de Juiz de Fora desenvolvido pela MKM Engenharia Ambiental. Após a determinação da área máxima urbanizável de cada RU foram elaborados os modelos para projeção da população nas RUs, seguindo uma tendência linear para o crescimento populacional até 2043 e um adensamento populacional máximo de acordo com o padrão de ocupação de cada uma delas. Para definir um valor máximo para o adensamento populacional foram selecionadas as RUs que apresentaram as maiores densidades e que já haviam ocupado toda sua área urbanizável.

Após a análise dos dados censitários de 1991, 1996 e 2000, foram adotados dois modelos que definem o padrão de crescimento das 81 RUs:

180 Modelo 1: representa as RUs que apresentaram decréscimo populacional entre os anos 1991 e 2000 e que, provavelmente, permanecerão com esta tendência até 2043.

Modelo 2: representa as RUs que apresentaram uma tendência de crescimento populacional entre 1991 e 2000 e que provavelmente permanecerão com esta tendência até o limite máximo de adensamento.

A aplicação dos modelos de projeção populacional possibilitou estimar a população (número de habitantes) e a densidade populacional líquida (número de habitantes/hectare) para cada uma das 81 Regiões Urbanas que compõem a Área urbana de Juiz de Fora no ano de 2043.

É importante ressaltar que, além da aplicação dos modelos de projeção populacional, foi considerada a hipótese de que $15 \%$ da população projetada para o ano de 2043 esteja localizada fora dos limites das RUs definidas no Plano Diretor de Desenvolvimento Urbano e que foram adotadas no estudo como unidades espaciais de análise. Diante das constatações verificadas no estudo dos diversos consumos per capita de Juiz de Fora, optou-se por adotar quatro padrões de consumo típicos para as áreas analisadas e extrapolar os resultados para o restante da cidade.

Dessa forma, tem-se uma população equivalente à disponibilidade de áreas à ocupação urbana do Município de Juiz de Fora, dentro do horizonte de projeto adotado nos estudos realizados pela MKM Engenharia Ambiental (2043), igual a 694.345 habitantes (representando um aumento de $57,7 \%$ em relação à população de 2000), valor obtido a partir da aplicação das atuais taxas censitárias médias de densidade demográfica às áreas urbanizáveis do município (ou seja, as áreas que não apresentam restrições legais à ocupação urbana) e de acordo com os parâmetros legais vigentes.

Comparando-se esse valor com a extrapolação da curva de tendência adotada para a população futura do Município de Juiz de Fora chega-se a um total de 816.852 habitantes, uma diferença de 15\% que representa a população que estará situada fora dos limites das RUs definidas no Plano Diretor de Desenvolvimento Urbano e que foram adotadas no estudo como unidades espaciais de análise. 
d) Classificação quanto à capacidade hídrica de suporte

Para a classificação das regiões hidrográficas de Angra dos Reis em importadoras ou exportadoras hídricas, procedeu-se ao cotejo dos seguintes valores de população equivalente, tal como proposto por Francisco (2004, p. 146):

1. População equivalente à demanda hídrica atual (Pop.demanda hídrica): corresponde à população atual.

2. População equivalente à quantidade hídrica disponível (Pop.quantidade hídrica disponível): corresponde à relação entre a vazão que pode ser outorgada e a demanda hídrica per capita atual.

3. População equivalente à qualidade hídrica (Pop.qualidade hídrica): é função do tipo de tratamento de esgoto adotado e do enquadramento dos corpos d'água receptores na Classe 2, conforme a Resolução CONAMA n. ${ }^{\circ}$ 357/2005.

4. População equivalente à disponibilidade de áreas à ocupação urbana (Pop.ocupação urbana): é resultado da aplicação das atuais taxas de densidade demográfica médias e dos parâmetros urbanísticos às áreas urbanizáveis previstas pelo arcabouço legal vigente referente ao uso e ocupação do solo (Plano Diretor de Desenvolvimento Urbano e Legislação Urbana Básica).

A classificação do município como importador ou exportador hídrico foi realizada a partir do cotejo entre os valores de população equivalente:

1. Regiões hidrográficas exportadoras: quando a Pop.quantidade hídrica disponível supera a Pop.ocupação urbana, caracterizando uma situação de superávit hídrico. Tais regiões são capazes de abastecer a população futura residente em seu território e ainda a população futura residente em regiões vizinhas.

2. Regiões hidrográficas importadoras: quando a Pop.quantidade hídrica disponível é menor ou próxima ao valor da Pop.ocupação urbana, podendo caracterizar um quadro de déficit hídrico futuro, necessitando importar água para sustentar a população aí residente ou, na melhor das hipóteses, manter a auto-suficiência na produção de água para abastecer a população futura residente.

3. Regiões hidrográficas críticas: quando a Pop.demanda hídrica já ultrapassa a Pop.quantidade hídrica disponível, caracterizando uma situação de déficit hídrico atual. Nestes casos, para que seja possível o abastecimento eficiente destas regiões, há necessidade que a água seja captada em outras bacias hidrográficas, preferencialmente daquelas classificadas como exportadoras.

São possíveis vários cenários. Levando-se em consideração todos os mananciais previstos pelo PDAA-AUJF para compor o futuro sistema de abastecimento de água do município e a otimização da vazão de regularização dos sistemas Norte e Dr. João Penido, conclui-se que a Pop.quantidade hídrica disponível supera a Pop.ocupação urbana. Assim, o Município de Juiz de Fora pode ser classificado como exportador hídrico, capaz de abastecer a população futura residente na área urbana, bem como a população residente nas áreas vizinhas. O superávit entre a Pop.quantidade hídrica disponível (4.653.682 habitantes) e a Pop.ocupação urbana (694.345 habitantes) seria de 3.959.337 habitantes.

Caso se considere um cenário mais realista para a Pop.quantidade hídrica disponível (825.268 habitantes, valor que corresponde ao cenário atual, representando o quantitativo populacional que poderá ser abastecido caso não haja a expansão do sistema de abastecimento municipal), o município 
ainda permanece na condição de exportador hídrico, porém com uma sensível redução do superávit da Pop.quantidade hídrica disponível em relação à Pop.ocupação urbana, que seria de 130.923 habitantes. Considerando-se uma Pop.ocupação urbana igual a 816.852 habitantes, que inclui a população que estará situada fora dos limites das RUs, mas mantendo-se o valor de Pop.quantidade hídrica disponível, o superávit seria de apenas 8.416 habitantes, aproximando definitivamente o município da condição de importador hídrico, capaz de garantir o abastecimento da população residente em seu território apenas com uma pequena margem de segurança. A não expansão do sistema de abastecimento municipal poderia até mesmo gerar uma situação de déficit hídrico futuro.

Em todos os cenários analisados, mesmo naquele que considera o somatório da atual capacidade de produção de água dos sistemas Norte e Dr. João Penido como a quantidade hídrica disponível do município, a Pop.quantidade hídrica disponível supera a Pop.demanda hídrica (520.612 habitantes, que corresponde à população atual do município), afastando-o da condição de região hidrográfica crítica.

Incluindo na análise o critério qualidade da água, têm-se também vários cenários possíveis. Quando a Pop.qualidade hídrica supera a Pop.ocupação urbana pode-se classificar uma determinada região como exportadora hídrica. No caso de Juiz de Fora, considerando-se a Pop.ocupação urbana igual a 694.345 habitantes e a Pop.qualidade hídrica igual a 275.089 habitantes (resultante da adoção do somatório da atual capacidade de produção de água dos sistemas Norte e Dr. João Penido como a quantidade hídrica disponível do município), caracterizando um cenário mais realista, é fácil perceber que a situação futura do município, caso não haja a expansão do sistema municipal de abastecimento de água, é crítica, já que a Pop.ocupação urbana supera a Pop.qualidade hídrica em 419.256 habitantes. Nessas condições, a Pop.demanda hídrica atual também já supera a Pop. qualidade hídrica em 245.523 habitantes, o que permite concluir que o Rio Paraibuna e seus principais afluentes, que atravessam as áreas mais densamente urbanizadas de seu território, já podem encontrar-se seriamente comprometidos com relação ao indicador qualidade hídrica, possivelmente apresentando alguns parâmetros físicos, químicos e biológicos com valores compatíveis a classes superiores (Classe 3 ou Classe 4) àquela definida pela legislação vigente (Classe 2), dependendo da porcentagem de domicílios atendidos pelo tratamento de esgoto e da vazão dos corpos d'água. Isso remete à necessidade de dispensar cuidados especiais ao tratamento dos esgotos domésticos no município. Deve-se trabalhar no sentido de efetivar a implantação do sistema de esgotamento sanitário de Juiz de Fora. A adoção de diferentes níveis de eficiência do tratamento dos esgotos domésticos, combinada às possibilidades de enquadramento dos corpos d'água nas classes de uso do CONAMA, pode fazer com que a vazão necessária para a diluição da DBO varie entre 1 e 83 vezes a vazão do efluente.

Adotando-se uma Pop.qualidade hídrica igual a 1.551.227 habitantes (possível de ser alcançada levando-se em consideração todos os mananciais previstos pelo PDAA-AUJF para compor o futuro sistema de abastecimento de água do município e também a otimização da vazão de regularização dos sistemas Norte e Dr. João Penido) e mantendo-se a Pop.ocupação urbana igual a 694.345 habitantes, o município passa à condição futura de exportador hídrico. O superávit seria de 856.882 habitantes da Pop.qualidade hídrica em relação à Pop.ocupação urbana. Dessa forma, o Rio Paraibuna e seus afluentes apresentariam disponibilidade hídrica superior à vazão necessária para garantir o abastecimento da população futura, diluir a DBO dos esgotos domésticos produzidos por esta população, atender às exigências legais de corpos d'água enquadrados na Classe 2 e abastecer a uma parcela significativa de população residente fora da área urbana de seu território. O quadro 1 apresenta um comparativo dos valores de população equivalente nos cenários de uso das águas e do solo analisados. 

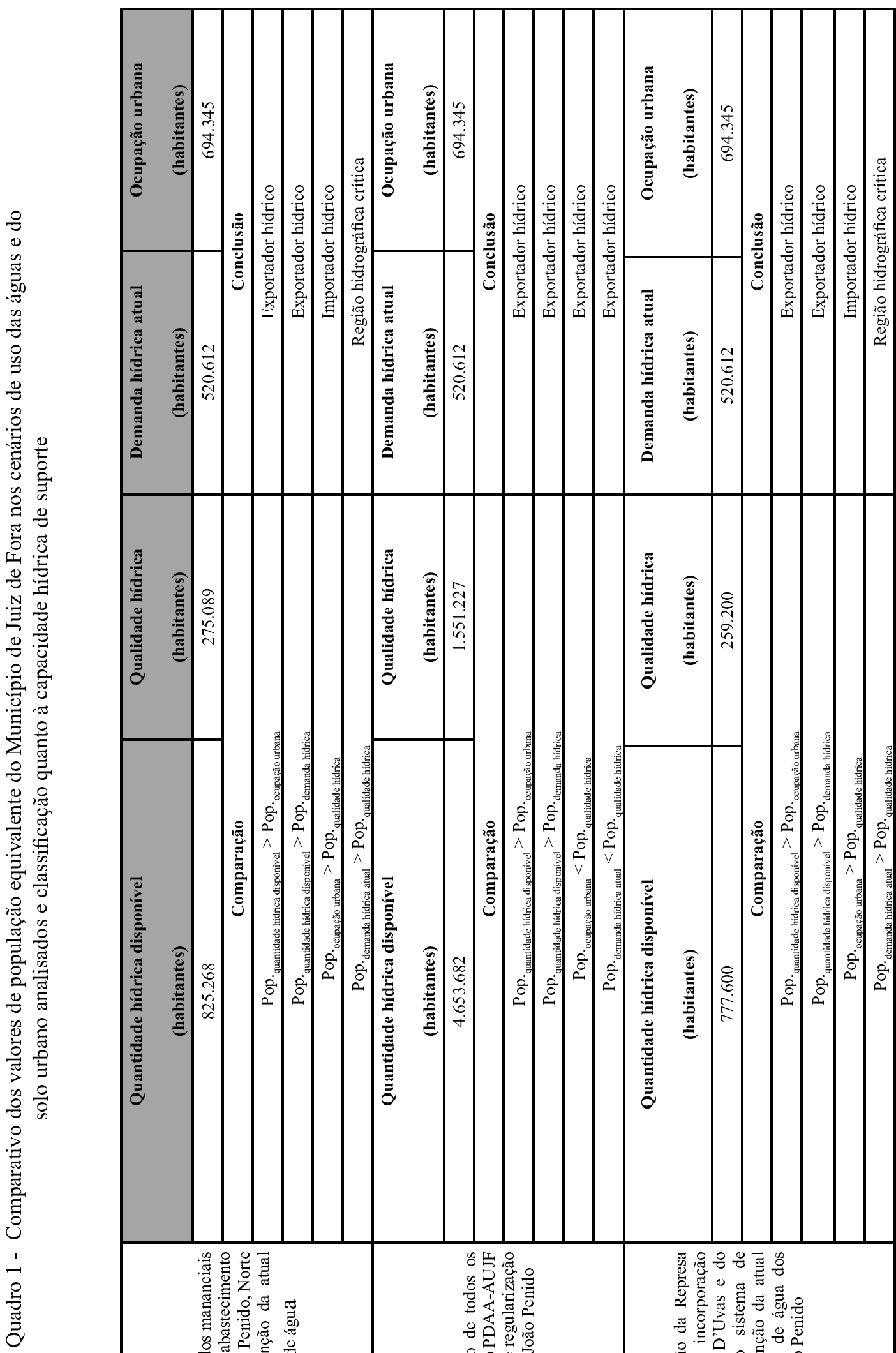

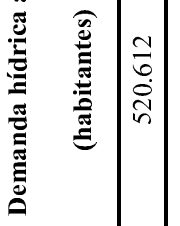
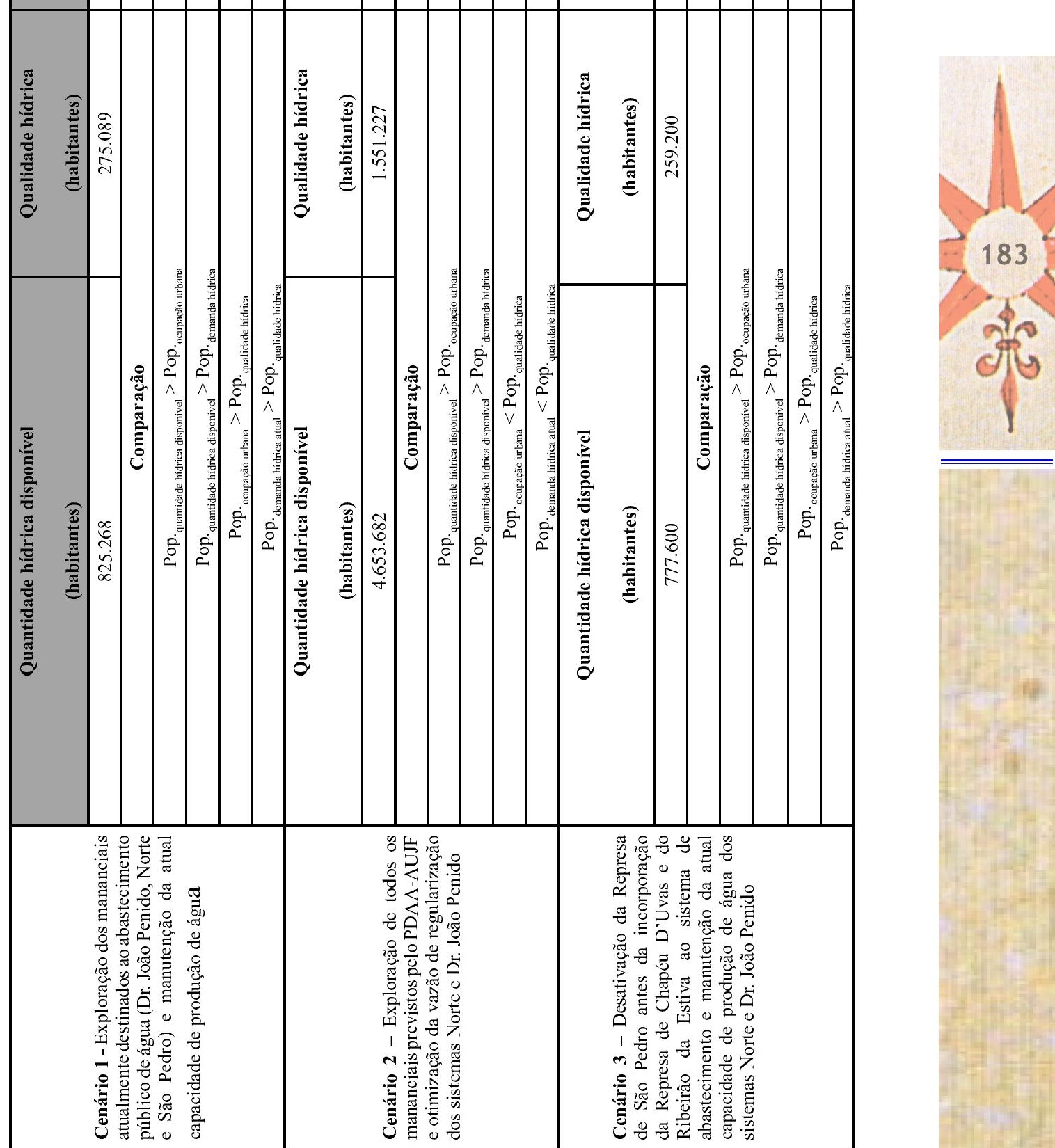


\section{e) Cenários de sustentabilidade do uso dos recursos hídricos}

Este item relaciona os critérios de capacidade hídrica de suporte, entendidos como limites ao crescimento demográfico, aos cenários de tendências demográficas projetados para as próximas quatro décadas.

No ano de 2002 a MKM Engenharia Ambiental, ao realizar o estudo de concepção do sistema de esgotamento sanitário de Juiz de Fora, apresentou as principais tendências demográficas do município, sobretudo no que concerne às projeções para o seu crescimento demográfico nas próximas décadas (MKM, 2002, p. 78 - Vol. I). O modelo de crescimento populacional desenvolvido no estudo baseou-se nos levantamentos populacionais já efetuados para a região, considerando ainda os estudos prévios porventura existentes. Para tanto, foram consultados os órgãos de recenseamento e de planejamento existentes em nível municipal, estadual e federal, objetivando verificar os censos disponíveis e as estimativas de crescimento da população já elaboradas.

A análise, realizada a partir do conhecimento dos dados primários e/ou secundários verificados, permitiu a apresentação de hipóteses a respeito da evolução e da distribuição da população de Juiz de Fora, através da geração de curvas de crescimento que permitiram aferir as projeções demográficas para o município.

O cenário de tendência mínima, que sugere uma taxa de crescimento demográfico anual declinante e superior à atualmente observada, não pode ser afastado em função da exaustão da tendência de migração interna para o campo e da elevação do padrão de vida da família brasileira associada à crescente inserção da mulher no mercado de trabalho, o que vem provocando a redução do número de filhos por casal em todo o país e, consequentemente, a redução significativa da taxa de crescimento populacional do município. Existe ainda uma tendência de que uma parcela significativa dos jovens de Juiz de Fora deixe a cidade em função da procura de emprego nos grandes centros urbanos e principais capitais do país.

O cenário de tendência de crescimento médio da população é aquele que observa a tendência verificada nas últimas quatro décadas no município. Neste cenário, o município apresentaria uma taxa anual média declinante ao longo do horizonte de projeto considerado, sem contudo atingir a estabilização.

O cenário de tendência de crescimento máximo da população é aquele que reflete a manutenção da taxa anual de crescimento demográfico ao longo do horizonte de projeto considerado. Esta hipótese é a menos provável de ocorrer, pois iria de encontro a uma tendência de redução do crescimento populacional discutida anteriormente e observada em todo o país e em Juiz de Fora em particular.

Considere-se primeiramente o cenário mais realista (Cenário 1). No caso da Pop.quantidade hídrica disponível e da Pop.qualidade hídrica, esse cenário adota os valores que levam em consideração somente os mananciais atualmente destinados ao abastecimento público de água, bem como as respectivas vazões atualmente exploradas. Dessa forma, tem-se uma Pop.quantidade hídrica disponível igual a 825.268 habitantes e uma Pop.qualidade hídrica igual a 275.089 habitantes. Nesse cenário, dos indicadores escolhidos para a avaliação da sustentabilidade hídrica do Município de Juiz de Fora, a qualidade hídrica revelou-se ser o mais restritivo. Nos três cenários de crescimento demográfico analisados, a Pop.qualidade hídrica já foi ultrapassada. A Pop.quantidade hídrica disponível seria ultrapassada no cenário de crescimento demográfico máximo somente por volta de 2033, revelando ser este o parâmetro menos restritivo entre aqueles analisados. Com relação à Pop. ocupação urbana, a mesma seria superada somente por volta de 2023 no cenário de crescimento demográfico máximo. Dessa forma, neste ano, as áreas urbanizáveis estariam totalmente ocupadas, registrando um adensamento populacional máximo. Levando-se em consideração a população que estará situada fora dos limites das RUs, tem-se uma Pop.ocupação urbana igual a 816.852 habitantes, devendo ser ultrapassada, no cenário de crescimento demográfico máximo, somente por volta de 2032. 


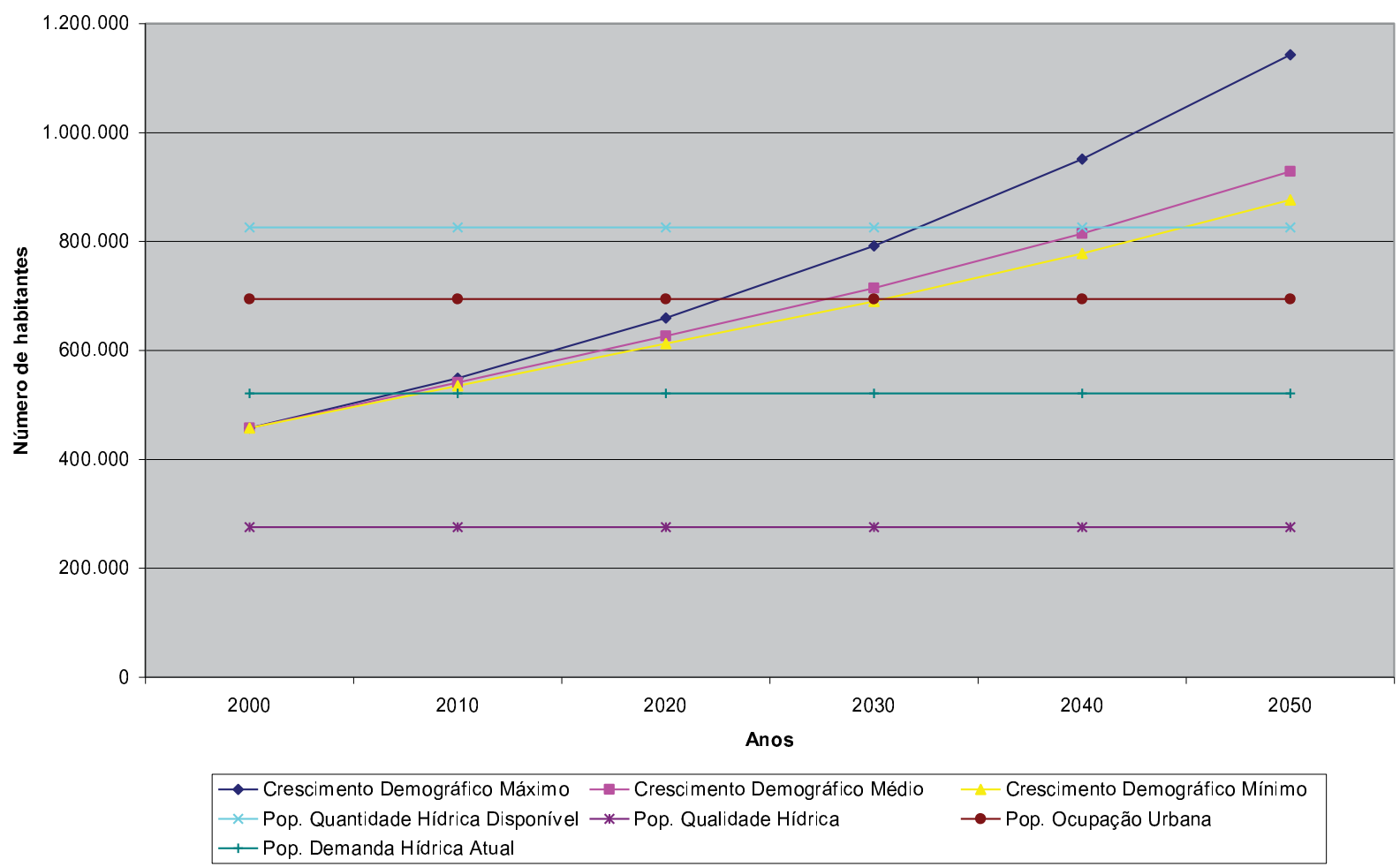

Figura 1 - Sustentabilidade do uso dos recursos hídricos em Juiz de Fora - Cenário 1

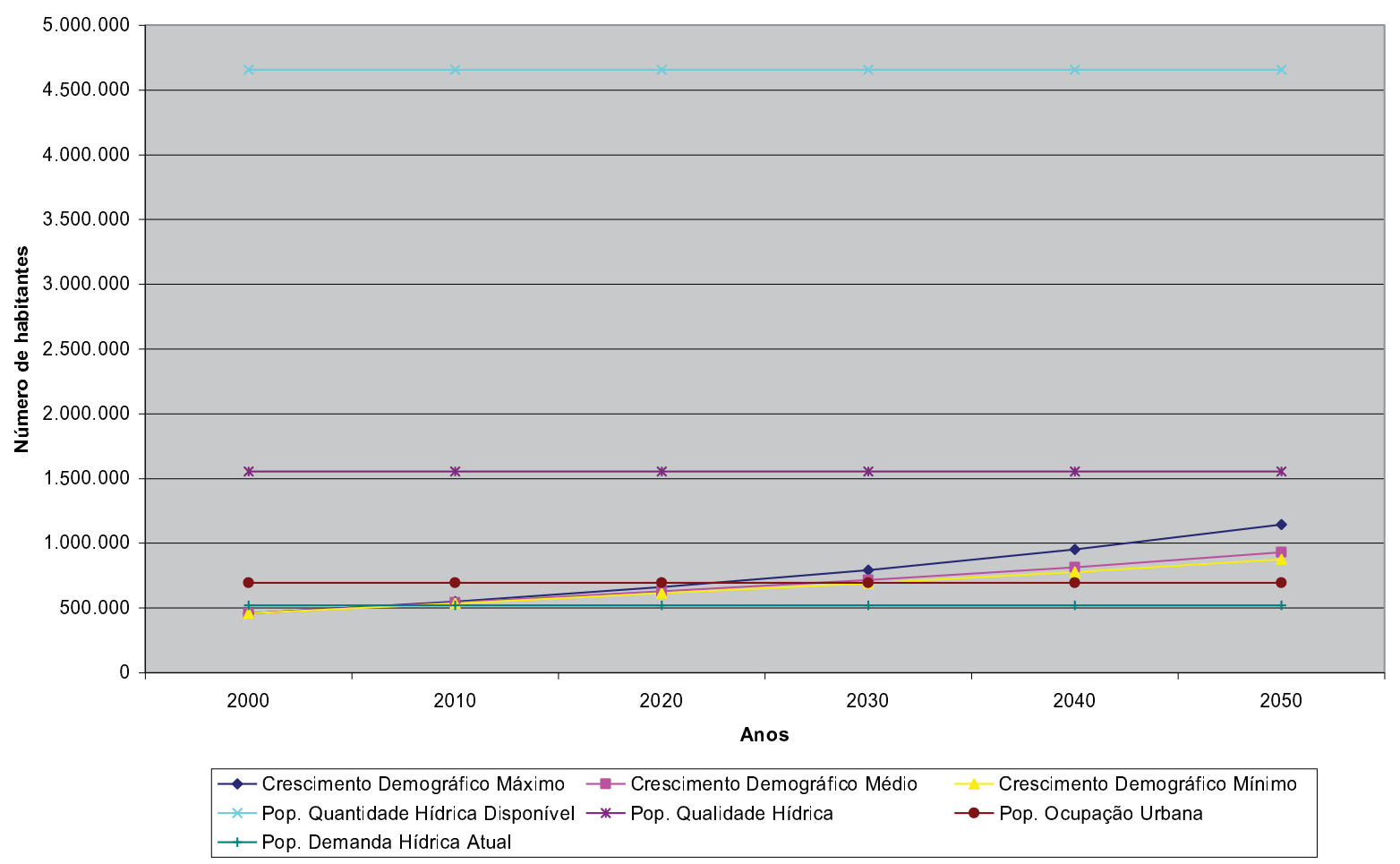

Figura 2 - Sustentabilidade do uso dos recursos hídricos em Juiz de Fora - Cenário 2 
O segundo cenário analisado é aquele que leva em consideração a utilização de todos os mananciais previstos no PDAA-AUJF e a otimização da vazão de regularização dos sistemas Norte e Dr. João Penido para o cálculo da Pop.quantidade hídrica disponível e da Pop.qualidade hídrica (Cenário 2). Nesse caso, tem-se uma Pop.quantidade hídrica disponível igual a 4.653.682 habitantes e uma Pop.qualidade hídrica igual a 1.551.227 habitantes. Nessas condições, as mais confortáveis, tanto a Pop.quantidade hídrica disponível quanto a Pop.qualidade hídrica não seriam ultrapassadas nos próximos 40 anos, em nenhum dos três cenários de crescimento demográfico analisados.

É possível ainda um terceiro cenário, que poderia ser considerado o mais crítico. Nesse cenário, considera-se a desativação da Represa de São Pedro antes da incorporação da Represa de Chapéu D’Uvas e do Ribeirão da Estiva ao sistema de abastecimento municipal e adota-se a atual capacidade de produção de água dos sistemas Norte e Dr. João Penido como a sua quantidade hídrica disponível (Cenário 3). Nesse cenário, a Pop.quantidade hídrica disponível seria igual a 777.600 habitantes e a Pop.qualidade hídrica igual a 259.200 habitantes. Nessas condições, a Pop.quantidade hídrica disponível seria ultrapassada, no cenário de crescimento demográfico máximo, somente por volta de 2030. Porém, a Pop.qualidade hídrica já foi ultrapassada nos três cenários de crescimento demográfico analisados. As Figuras 1, 2 e 3 apresentam a representação gráfica dos três cenários de sustentabilidade hídrica analisados para o Município de Juiz de Fora.

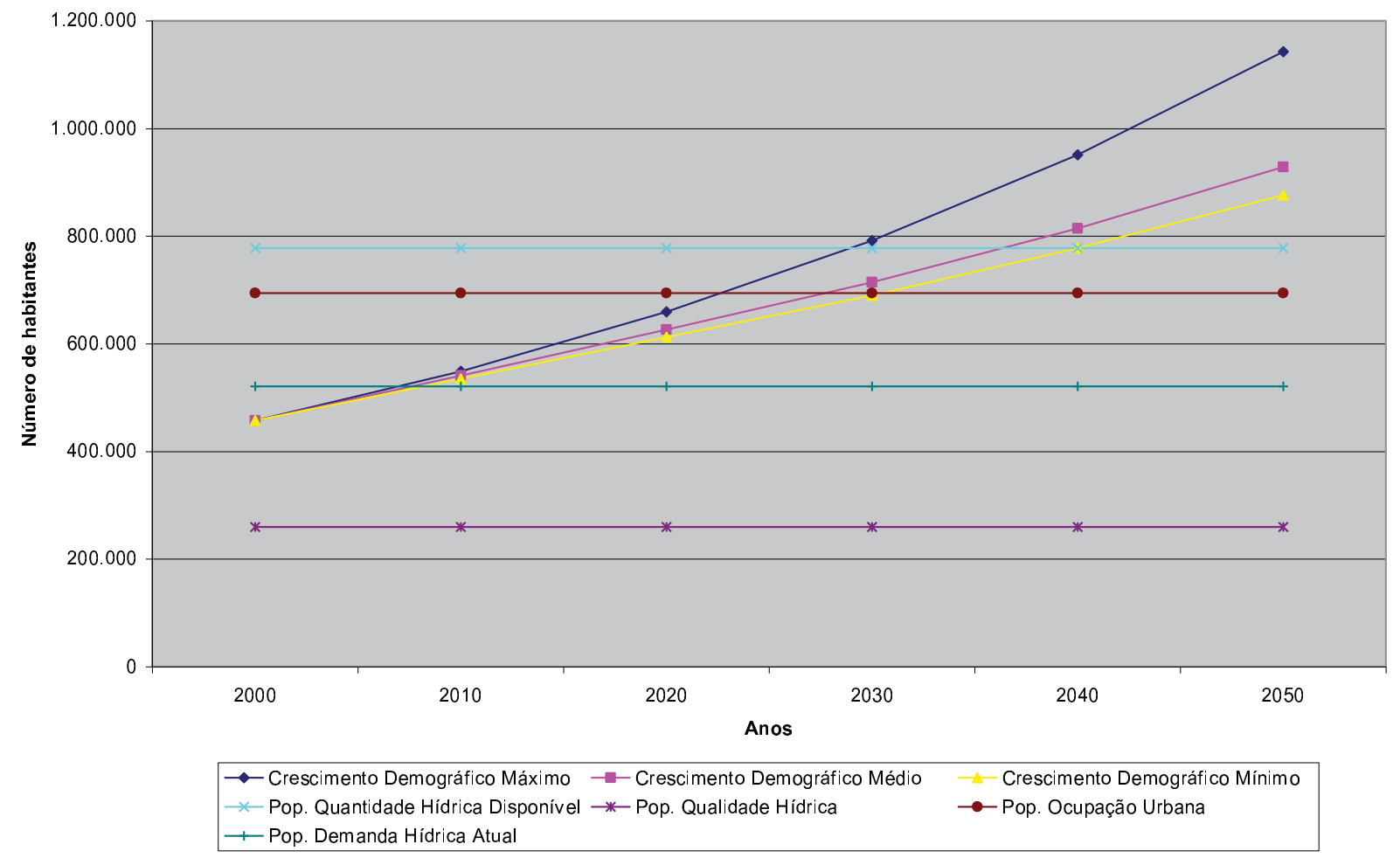

Figura 3 - Sustentabilidade do uso dos recursos hídricos em Juiz de Fora - Cenário 3

\section{CONSIDERAÇÕES FINAIS}

Primeiramente, é importante ressaltar que os resultados aqui apresentados não correspondem a valores populacionais preconizados como meta para qualquer política de planejamento, mas sim como indicadores de uma situação hipotética, resultante da forma como os recursos hídricos podem ser utilizados de forma sustentável em âmbito municipal, auxiliando no processo de tomada de decisões na gestão de tais recursos.

Os valores de população equivalente variaram entre 259.200 e 4.653 .682 habitantes, dependendo do indicador e das condições consideradas. O maior valor de população equivalente corresponde à 
relação entre a quantidade hídrica disponível e a demanda hídrica per capita atual. A nível técnico não deve haver barreiras locais intransponíveis para que esta quantidade máxima de água disponível seja utilizada. O menor valor de população equivalente corresponde aos limites estabelecidos pela qualidade hídrica. Porém, na medida em que venham a ser introduzidos sistemas de tratamento de esgotos mais eficientes ou que os sistemas existentes e projetados tenham sua capacidade de atendimento ampliada, a população equivalente à qualidade hídrica pode ser também ampliada em até 20 vezes. Associando-se essa possibilidade ao atendimento de pré-requisitos mais exigentes da Resolução CONAMA n. ${ }^{\circ}$ 357/2005 relativos ao enquadramento dos corpos d'água, pode-se alcançar valores até 83 vezes superiores.

Juiz de Fora é um município relativamente privilegiado em termos de disponibilidade de recursos hídricos, com um potencial significativo ainda a ser explorado. A exploração futura desse potencial permitirá a elevação significativa dos valores de quantidade hídrica per capita disponível. Atualmente, a quantidade hídrica disponível é capaz de atender à demanda hídrica de forma satisfatória. Porém, na área abastecida pela Represa de São Pedro, essa relação já é deficitária há algum tempo, necessitando o abastecimento ser complementado pelos sistemas Dr. João Penido e Norte na época de estiagem.

Outro fator a ser considerado diz respeito à desigual distribuição da população e das águas superficiais no território municipal, fator que deverá ser levado em consideração na definição da política de expansão do sistema de abastecimento e distribuição de água. Como visto, o abastecimento público de água do município é basicamente realizado a partir da exploração de três mananciais superficiais: A Represa de São Pedro, a Represa Dr. João Penido e o Ribeirão do Espírito Santo. A Represa de São Pedro, em função da baixa disponibilidade hídrica e do avançado processo de degradação ambiental desencadeado pela ocupação intensa e desordenada de sua bacia hidrográfica, poderá ser desativada pela CESAMA caso não sejam implementadas medidas visando a recuperação ambiental de sua bacia hidrográfica. Com relação à Represa Dr. João Penido, investimentos podem ser feitos no sentido de explorar de forma mais eficiente o potencial de sua bacia hidrográfica. A represa abastece atualmente a maior parte da população do município, ficando sobrecarregada na época de estiagem. Com relação ao Ribeirão do Espírito Santo, este é certamente o manancial, entre aqueles atualmente utilizados, com o maior potencial para expansão da capacidade de atendimento. Em razão de sua proximidade com a área urbana, da baixa densidade de ocupação de sua bacia hidrográfica e de seu elevado potencial hídrico, não restam dúvidas de que este será um manancial de fundamental importância para Juiz de Fora no século XXI.

Porém, o manancial que deverá ocupar o lugar de destaque nas discussões a respeito do abastecimento de água da cidade nos próximos anos é, também sem dúvida nenhuma, a Represa de Chapéu D'Uvas. Esse manancial pode representar a auto-suficiência de Juiz de Fora, a longo prazo, em termos de abastecimento de água. Localizada em território dos municípios de Ewbanck da Câmara e de Santos Dumont, é fato que a represa deverá ser futuramente utilizada no abastecimento público de água da população de Juiz de Fora, o que reforça a necessidade da definição de políticas públicas comuns por parte das administrações municipais envolvidas com o objetivo de oferecer as condições necessárias para a múltipla utilização de suas águas e, principalmente, a proteção de tão importante manancial contra os processos de degradação ambiental.

Apesar da Represa de Chapéu D’Uvas representar, indiscutivelmente, a garantia do abastecimento público de água de Juiz de Fora no século XXI, é importante mais uma vez ressaltar aqui a necessidade de priorizar a utilização dos mananciais atualmente explorados no município. A adoção de medidas de recuperação ambiental das bacias hidrográficas desses mananciais, somada aos investimentos para a expansão de sua capacidade de atendimento, garantiria o atendimento da demanda hídrica atual e mesmo de uma significativa demanda hídrica futura, abrindo-se a possibilidade para que a Represa de Chapéu D’Uvas permaneça como um manancial estratégico de 
reserva e evitando-se os possíveis inconvenientes resultantes de sua incorporação ao sistema de abastecimento público de água de Juiz de Fora, entre os quais pode-se citar os custos adicionais para a adução e o tratamento.

Finalmente, é fundamental citar aqui a urgente necessidade de canalização de investimentos para o tratamento dos esgotos domésticos em Juiz de Fora. Os números relativos à coleta são bastante satisfatórios, abrangendo a quase totalidade da população urbana do município, que representa a maioria absoluta da população municipal. Porém, quanto ao tratamento, os índices ainda são muito baixos para uma cidade do porte de Juiz de Fora e que deseja firmar-se no cenário regional como um centro polarizador e de atração de investimentos. O principal fator que explica o comprometimento da qualidade das águas do Rio Paraibuna é o lançamento in natura da maior parte dos esgotos domésticos produzidos em Juiz de Fora e nas demais cidades que são banhadas pelas suas águas, o que reforça a urgente necessidade de se complementar a implantação do sistema de esgotamento sanitário municipal.

\section{REFERÊNCIA BIBLIOGRÁFICA}

BRANCO, S. M. e ROCHA, A. A. Poluição, proteção e usos múltiplos de represas. São Paulo: Edgard Blücher/CETESB, 1977.

CARRERA-FERNANDEZ, J. e GARRIDO, R. J. Economia dos recursos hídricos. Salvador: EDUFBA, 2003.

CONSELHO NACIONAL DO MEIO AMBIENTE. Resolução n. ${ }^{\mathbf{3 5 7}}$, de 17 de março de 2005. Dispõe sobre a classificação dos corpos de água e diretrizes ambientais para o seu enquadramento, bem como estabelece as condições e padrões de lançamento de efluentes, e dá outras providências. Brasília: CONAMA, 2005. Disponível em: <http://www.mma.gov.br/port/conama>. Acesso em 15 de março de 2007.

CRUZ, J. C. Disponibilidade hídrica para outorga: avaliação de aspectos técnicos e conceituais. 2001. Tese (Doutorado em Engenharia) - Instituto de Pesquisas Hidráulicas, UFRGS, Porto Alegre, 2001.

FRANCISCO, C. N. Subsídios à gestão sustentável dos recursos hídricos no âmbito municipal: o caso de Angra dos Reis, RJ. 2004. Tese (Doutorado em Geociências) - Centro de Estudos Gerais, UFF, Niterói, 2004.

INSTITUTO BRASILEIRO DE GEOGRAFIA E ESTATÍSTICA. Produto Interno Bruto a preços correntes e Produto Interno Bruto per capita segundo as Grandes Regiões, Unidades da Federação e Municípios 2002-2005. Rio de Janeiro: IBGE, 2005. Disponível em: <http://www.ibge.gov.br/home/estatistica/economia/ pibmunicipio s/2005/tab01.pdf $>$. Acesso em 20 de setembro de 2009.

INSTITUTO BRASILEIRO DE GEOGRAFIA E ESTATÍSTICA. Estimativas das populações residentes, em 1. ${ }^{\circ}$ de julho de 2009, segundo os municípios. Rio de Janeiro: IBGE, 2009. Disponível em: $<$ http://www. ibge. gov.br/home/estatistica/populacao/estimativa2008/POP2008_DOU.pdf $>$. Acesso em 20 de setembro de 2009.

INSTITUTO MINEIRO DE GESTÃO DAS ÁGUAS. Portaria n. ${ }^{\circ}$ 10, de 30 de dezembro de 1998. Altera a redação da Portaria n. ${ }^{\circ}$ 30, de 07 de junho de 1993. Belo Horizonte: IGAM, 1998. Disponível em: <http:// www.siam.mg.gov.br/sla/download.pdf ?idNorma=669>. Acesso em 15 de março de 2007.

LEME ENGENHARIA S.A. Plano Diretor de Abastecimento de Água da Área Urbana de Juiz de Fora: Introdução. Juiz de Fora: Leme Engenharia/PJF, 1985. v. 1.

MKM ENGENHARIA AMBIENTAL LTDA. Estudo de concepção do sistema de esgotamento sanitário de Juiz de Fora: estudos preliminares e projeção populacional. Juiz de Fora: MKM/PJF, 2002. v. 1.

MOTA, S. Preservação e conservação de recursos hídricos. 2. ${ }^{a}$ ed. Rio de Janeiro: ABES, 1995.

PREFEITURA DE JUIZ DE FORA. Juiz de Fora sempre: Plano Diretor de Desenvolvimento Urbano. Juiz de Fora: Funalfa Edições, 2004. 